\title{
EVALUAREA NON-INVAZIVĂ A FIBROZEI HEPATICE CU AJUTORUL ELESTOGRAFIEI HEPATICE (FIBROSCAN) LA PACIENŢII CU INFECŢIE CRONICĂ VHB ŞI VHC
}

\author{
Andreea Rădășan², Mihai Voiculescu ${ }^{1,2}$, Laura Elena Iliescu ${ }^{1,2}$ \\ ${ }^{1}$ Universitatea de Medicină şi Farmacie „Carol Davila“, Bucureşti, România \\ ${ }^{2}$ Centrul de Medicină Internă , Institutul Clinic Fundeni, Bucureşti, România
}

\begin{abstract}
REZUMAT
Introducere. În ultimii ani, s-au făcut progrese majore în ceea ce priveşte tratamentul şi prevenţia hepatitelor virale, însă această patologie reprezintă încă o problema majoră de sănătate şi socioeconomică. Elementul definitoriu pentru această boală este reprezentat de fibroza hepatică, componentă histologică dosebit de importantă datorită rolului sau în constituirea leziunilor hepatice de ciroză hepatică. Astfel, o etapă esenţială în depistarea şi monitorizarea hepatitei virale, o reprezintă detectarea şi măsurarea fibrozei hepatice. Astăzi dispunem de metode invazive de depistare a fibrozei hepatice, puncţia biopsie hepatică, precum şi de metode non-invazive, care la rândul lor se împart în metode serice şi metode imagistice (2).

Scopul studiului. Scopul acestui studiu este de a determina dacă elastografia transcutană (FibroScan), metodă imagistică, non-invazivă de elecţie, este la fel de fiabilă în cazul hepatitei virale B, ca şi în cazul hepatitei virale $\mathrm{C}$.

Materiale şi metodă: Au fost luaţi în studiu un număr de 1127 pacienţi, având o afecţiune hepatică de etiologie VHB şi VHC. Aceşti pacienţi au fost examinaţi cu ajutorul FibroScan în perioada lulie 2009 - Aprilie 2011.

Rezultate: Din cei 1127 pacienţi investigaţi cu ajutorul FibroScan-ului, 40 dintre aceştia au efectuat şi Puncţie Biopsie Hepatică. Dintre aceştia, $82 \%$ au obţinut aceleasi stadii ale fibrozei hepatice la cele două investigaţii, iar $18 \%$ au obţinut grade de fibroză diferite la cele două teste. Comparativ, la pacienţii cu virus hepatitic C, am obţinut o concordanţă de $67,81 \%$ a celor două teste non-invazive, FibroScan şi FibroMax şi o concordanţă de 79,16\% a FibroScan-ului comparativ cu Biopsia Hepatică. Pentru virusul B, concordanţa este chiar mai bună de $75 \%$ (FibroScan - FibroMax), respectiv $80 \%$ pentru FibroScan - $\mathrm{PBH}$.

Concluzii: FibroScan este una din metodele de evaluare non-invazivă a fibrozei hepatice cu acurateţe diagnostică asemănătoare FibroMax-ului şi apropiată de a Puncţiei Biopsie Hepatică.
\end{abstract}

Cuvinte cheie: Hepatită B, Hepatită C, FibroScan, FibroMax, Fibroză, acurateţe, concordanţă

\section{INTRODUCERE}

Fibroza hepatică este o componentă histologică importantă în constituirea leziunilor hepatice de ciroză hepatică. Fibroză poate fi întâlnită și în alte afecțiuni hepatice, nu numai în ciroză, dar în această afecțiune reprezintă componenta esențială, definitorie pentru boală. Consecințele imediate ale fibrozei sunt reprezentate de dezorganizarea structurii hepatice și de înlocuire a țesutului hepatic funcțional cu un țesut amorf, nefuncțional. Depistarea și evaluarea fibrozei hepatice reprezintă o etapă importantă în diagnosticul bolii hepatice. Studii recente arată că fibroza hepatică, cel puțin până la un anumit stadiu de evoluție, poate fi oprită și eventual s-ar putea obține regresia acesteia prin înlăturarea cauzei și stoparea fibrogenezei. În aceste

Autor corespondent:

Andreea Rădășan, Universitatea de Medicină şi Farmacie „Carol Davila“, Strada Dionisie Lupu 37, București

E-mail: andreea.radasan@gmail.com 
condiții, este imperios necesar să beneficiem de unul sau mai multe metode de monitorizare a fibrozei hepatice (2).

Metodele de depistare ale fibrozei sunt de mai multe tipuri. Metodele de depistare precoce ale fibrozei hepatice sunt invazive, reprezentate de puncția biopsie hepatică și metode noninvazive. Metodele non-invazive sunt la rândul lor de mai multe tipuri: markeri serici (direcți și indirecți) și metode imagistice. Markerii direcți sunt rar folosiți în studii clinice, fiind de obicei utilizați în cercetarea fundamentală. De-a lungul timpului a existat o competiție între metodele invazive și noninvazive de diagnostic al fibrozei hepatice. Principalul avantaj al metodelor invazive, reprezentate de puncția biopsie hepatică, este acela că oferă și posibilitatea aprecierii modului în care este distribuită fibroza în contextul arhitecturii hepatice. Puncția biopsie hepatică, totodată, oferă avantajul diagnosticării leziunilor asociate, cum sunt încărcarea grasă, depunerea de fier, necroză etc. Biopsia are și dezavantaje, dintre care cele mai importante sunt caracterul traumatic și reprezentativitatea fragmentului, ținând seama că cel mai bun fragment nu reprezintă decât $1 / 50.000$ din masa hepatică. Testele non-invazive sunt mai ieftine și după cum este și denumirea, sunt atraumatice și pot fi repetate ori de câte ori este nevoie. Acuratețea lor însă, este în unele cazuri scăzută, așa că avem nevoie de un „consorțiu“ de teste indirecte pentru o imagine fidelă asupra fibrozei hepatice. Dintre aceste teste, FibroScan s-a impus ca o metodă imagistică, cu acuratețe diagnostică bună raportată la puncția biopsie hepatică, considerat „gold-standard-ul“ evaluării leziunii hepatice (1-3).

\section{SCOPUL STUDIULUI}

Având în vedere că tot mai mulți pacienți refuză categoric puncția biopsie hepatică, preferând o metodă non-invazivă, scopul acestui studiu a fost de a determina acuratețea evaluării fibrozei hepatice cu ajutorul elastografiei transcutane, la pacienții cu infecție cronică VHB. Infecția cronică VHB reprezintă, în România, o problemă de sănătate cel puțin la fel de mare cu cea a hepatitei cronice VHC, în ciuda existenței unei metode de prevenție. Astfel, pacientul își dorește o metodă de evaluare a fibrozei hepatice, în primul rând non-invazivă, iar apoi, cu un cost scăzut și reproductibilitate mare.

Obiectivele principale ale studiului sunt:

1. Testarea acurateței rezultatelor FibroScan în evaluarea fibrozei hepatice la pacientii cu hepatita cronica VHB.

2. Compararea rezultatelor FibroScan cu rezultatele Puncției Biopsie Hepatică și cu cele obținute la FibroMax și încercarea de a demonstra care este cea mai bună metodă non-invazivă de detecție a fibrozei hepatice.

3. Compararea rezultatelor FibroScan la pacienții cu infecție cronică VHB cu cele ale pacienților VHC.

\section{MATERIALE ŞI METODĂ}

Studiul realizat este de tip prospectiv. Datele necesare studiului au fost preluate din foaia de observație a pacienților internați în secția de Medicină Internă a Institutului Clinic Fundeni, în perioada Iulie 2009 - Aprilie 2011. Au fost incluși 1127 pacienți cu infecție virală VHB și VHC. Aceștia au fost internați în Clinica de Medicină Internă - Fundeni în perioada Iulie 2009 - Aprilie 2011. Criteriile de includere sunt reprezentate de pacienți cu afectare hepatică virală (VHB, VHC) dovedită prin teste virusologice, cu și fără tratament antiviral. Criteriile de excludere sunt reprezentate de pacienți cu ascită, sarcină, dispozitive de stimulare cardiacă și obezitate.

Subiecții au fost examinați cu ajutorul aparatului FibroScan Nr. 502 elaborat de Echosens (Paris, Franța). Datele au fost introduse într-o singură bază de date MS Access 2010. Pentru grafice și calcule statistice au fost folosite MS Excel 2010 și IBM SPSS Statistics 19. 


\section{REZULTATE}

Acești pacienți au fost examinați cu ajutorul FibroScan în perioada Iulie 2009 - Aprilie 2011. Fiecărui pacient i s-a efectat cel puțin o examinare FibroScan, astfel încât numărul total de testări elastografice ale acestor pacienți este de 2355. Vârsta medie a pacienților este de 52,5 ani. Dintre acești 1127 pacienți, 501 (44,45\%) au fost bărbați și 626 femei $(55,54 \%)$ repartiția pe sexe fiind aproximativ egală (Fig. 1).

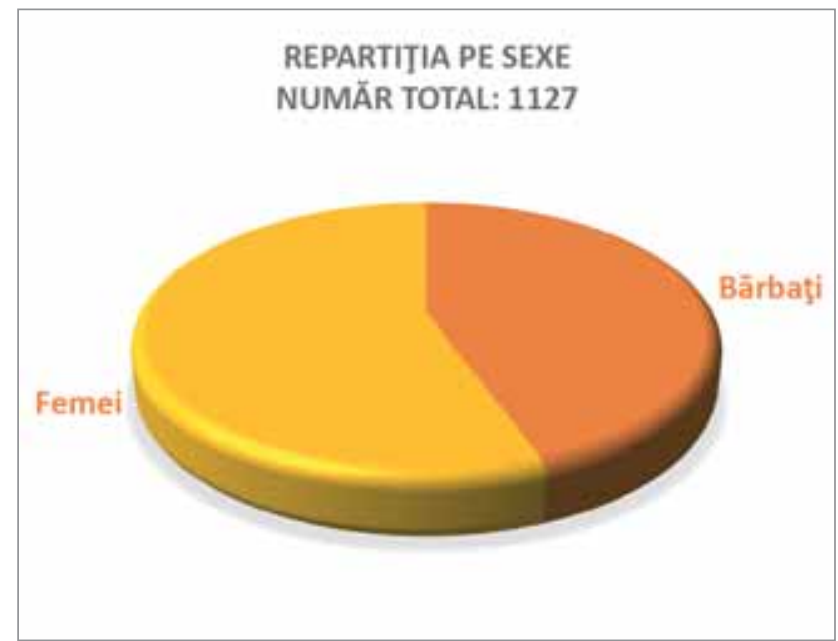

Figura 1. Repartiţia pe sexe a pacienţilor

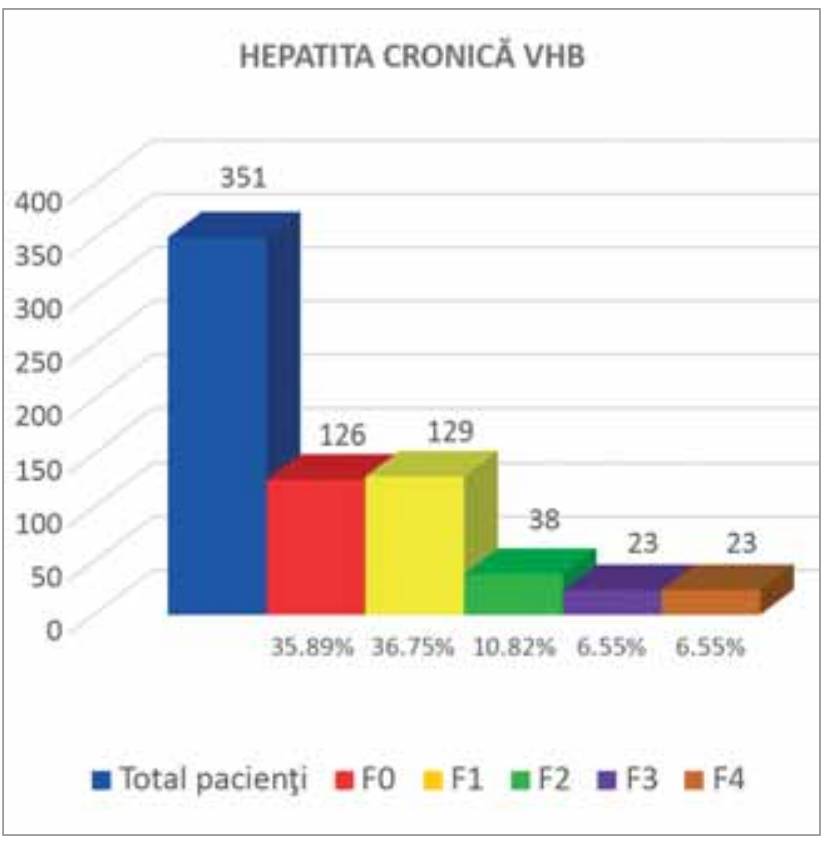

Figura 2. Gradele de fibroză hepatică la pacienţii cu hepatită cronică VHB

Din totalul de 1127 pacienți, 351 (31,14\%) au fost diagnosticați cu infecție cronică VHB, aceștia având o ușoară predominență a sexului feminin $(58,97 \%)$ comparativ cu sexul masculin (41,02\%). Dintre aceștia, 339 de pacienți $(96,58 \%)$ au efectuat FibroScan. Pentru un procent de $3.41 \%$, examinatorul nu a putut obţine un rezultat elastografic, din motive tehnice: obezitate, meteorism abdominal accentuat etc. Doar 72 de pacienți $(20,51 \%)$ au efectuat testul FibroMax.

În figura 2 se observă că majoritatea pacienților au obținut rezultate în intervalele de fibroză F0 și F1 (F0=35,89\%, F1=36,75\%). Într-un procent mult mai mic se regăsesc pacienții cu fibroză medie, F2 (10,82\%) și foarte puțini sunt cei cu grade avansate de fibroză (F3=6,55\%, F4=6,55\%) (Fig. 2).

Studiul comparativ s-a efectuat pentru un numar de 571 pacienti cu hepatita cronica VHC $(50,66 \%)$. Și aici se observă predominanța sexului feminin, 65,84\% (376 pacienți), comparativ cu sexul masculin, 34,15\% (195 pacienți). Din cei 571 de pacienți cu virus hepatitic C, 15 subiecți $(2,62 \%)$ nu au putut realiza un rezultat FibroScan din aceleași motive tehnice prezentate mai sus (obezitate, meteorism abdominal accentuat). Spre deosebire de pacienții cu infecție

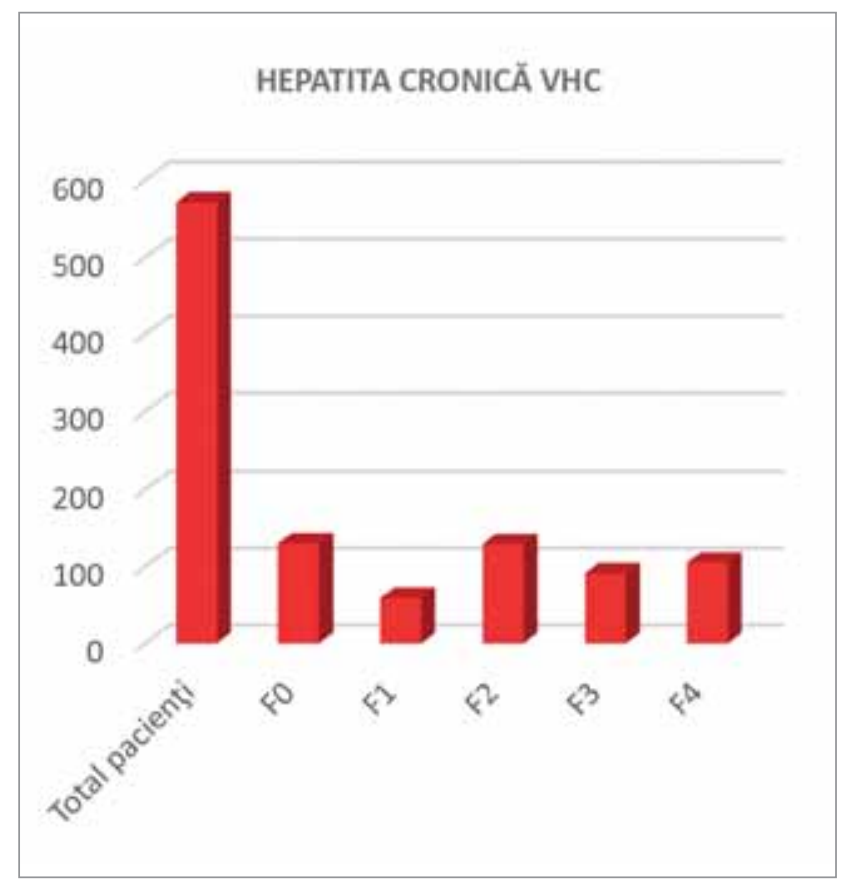

Figura 3. Gradele de fibroză hepatică la pacienţii cu hepatită cronică VHB 
VHB, la subiecții diagnosticați cu hepatită cronică VHC, s-au obținut procente aproximativ egale în intervalele de fibroză F0 (19,26\%), F1 $(28,54 \%)$ și F2 (19,08\%), cu o ușoară predominență a fibrozei medii, F2. Totuși, o fibroză avansată, F3 și F4 a fost identificată într-un procent mai mare decât în cazul hepatitei VHB, F3=14,18\% și F4=16,63\% (Fig. 3).

Din totalul de 1127 subiecți, 55 pacienți $(4,88 \%)$ au fost diagnosticați cu ciroză hepatică VHB. Dintre aceștia, 60\% (33 subiecți) au fost bărbați și 40\% (22 subiecți) au fost femei. Un număr de 3 pacienți nu a putut obține un rezultat la examinarea FibroScan datorită obezității, meteorismului abdominal și lichidului de ascită. Pacientii diagnosticati cu ciroza hepatica VHB, majoritatea (65.45\%) au obtinut valori cuprinse in intervalul de fibroza F4. Un procent de $18.18 \%$ a obtinut un scor de fibroza F3 METAVIR, iar in intervalul F0 nu se situeaza niciun pacient (Fig. 4). Sapte pacienti au optat sa efectueze ambele teste, FibroScan si FibroMax.

În ceea ce privește ciroza hepatică VHC, numărul de pacienți investigați este mult mai mare, 154 pacienți $(13,66 \%)$. Dintre aceștia, 88 subiecți $(57,14 \%)$ sunt femei și 66 subiecți

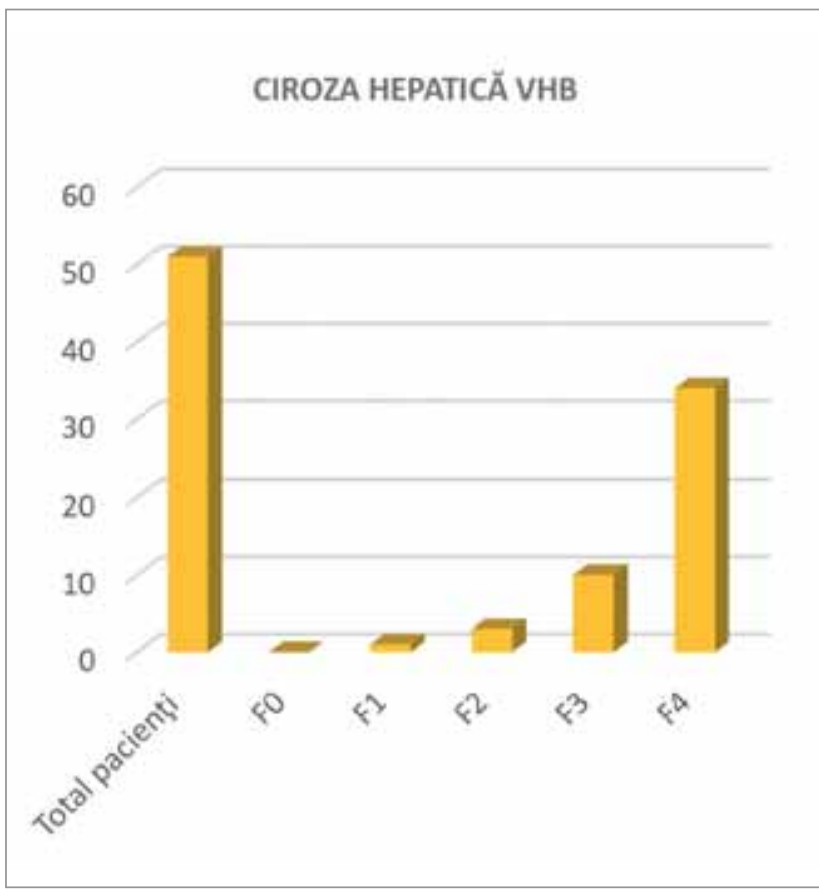

Figura 4. Gradele de fibroză hepatică la pacienţii cu ciroză hepatică VHB
$(42,85 \%)$ sunt bărbați. Doar 5 pacienți au avut dificultăți în a obține un rezultat FibroScan, și 21 din cei 154 au optat pentru a efectua ambele teste, FibroMax și FibroScan. De asemenea, la pacienții diagnosticați cu ciroză hepatică VHC, s-a obținut într-un procent de $84,41 \%$ un scor de fibroză F4, iar în intervalul F0 nu s-a situat nici un pacient (Fig. 5).

FibroScan și FibroMax sunt principalele teste non-invazive de evaluare a fibrozei hepatice disponibile în prezent. FibroScan a fost validat inițial, pentru infecția cu virusul hepatitic C, fi-

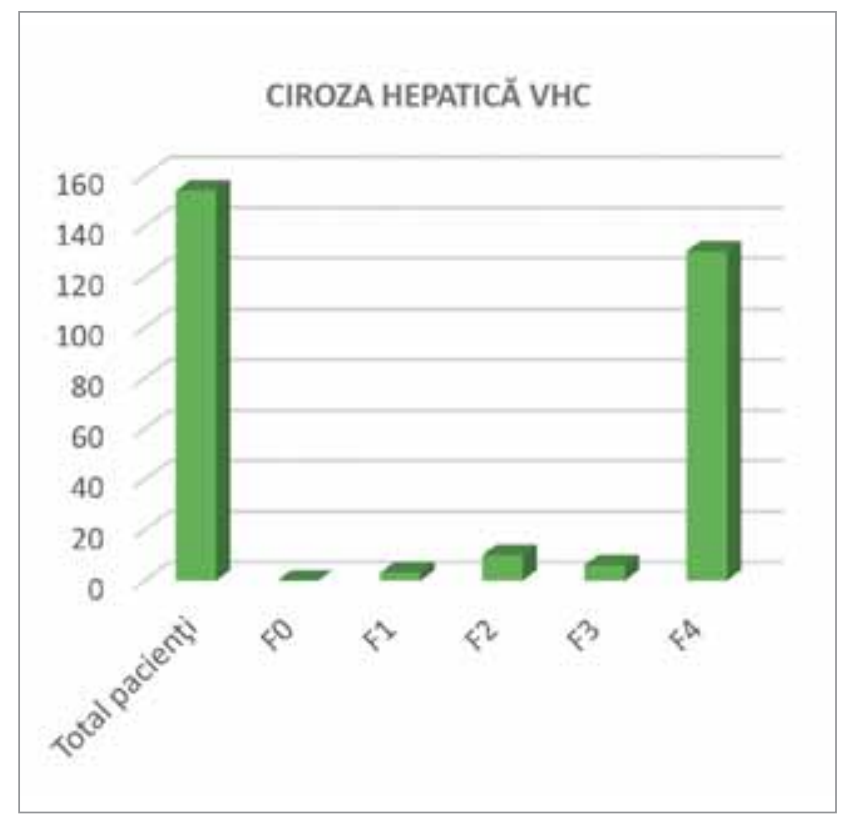

Figura 5. Gradele de fibroză hepatică la pacienţii cu ciroză hepatică VHC

ind inclus de curând în ghidul de diagnostic și tratament al infecției cronice VHB, iar FibroMax este validat pentru toate hepatitele cronice virale (8-10). Pacienții din acest studiu au fost evaluați cu ajutorul ambelor teste, FibroScan (1127 pacienti) si FibroMax (187 pacienti). În ceea ce privește hepatita cronică VHB, s-a obținut o concordanță a celor două teste de $75 \%$ (grade de fibroză similare). O diferență de numai un grad s-a obținut la 9 pacienți, iar o diferență de 2 sau mai multe grade de fibroză s-au obținut la 8 pacienți. Dintre cei 8 pacienți, 5 au efectuat testul FibroMax cu 1-2 ani anterior examinării FibroScan. 


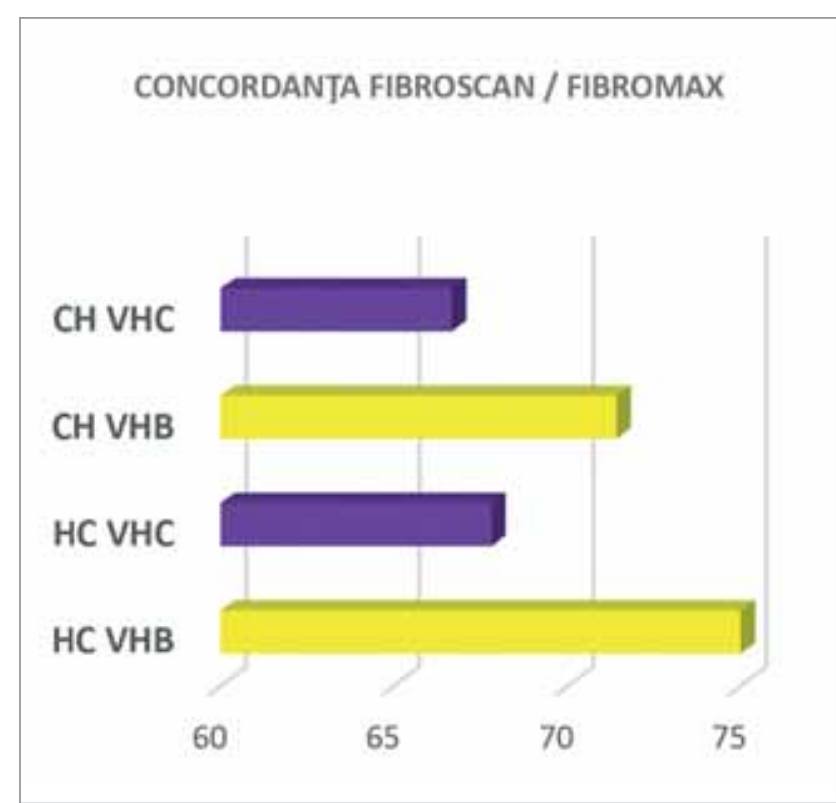

Figura 6. Concordanţa celor două tipuri de evaluare noninvazivă a fibrozei hepatice

În hepatita cronică VHC, s-a obținut o concordanță de 67,81\%. 0 diferență de 2 sau mai multe grade s-a obținut la 14 pacienți.

În cazul cirozei hepatice VHB, concordanța obținută a fost de 71,42\%. Doi pacienți au obținut o valoare mai mare la FibroScan comparative cu FibroMax, dar au efectuat FibroMax cu 1-2 ani anterior examinării elastografice. Concordanța în ciroză hepatică VHC a fost de 66,66\%.

Comparativ, la pacienţii cu virus hepatitic C am obținut o concordanță de 67,81\% a celor două teste non-invazive, FibroScan și FibroMax și o concordanță de 79,16\% a FibroScan-ului comparativ cu Biopsia Hepatică (Fig. 6). Pentru virusul $\mathrm{B}$, concordanța este chiar mai bună de 75\% ( FibroScan - FibroMax), respectiv 80\% pentru FibroScan - PBH (Fig. 7).

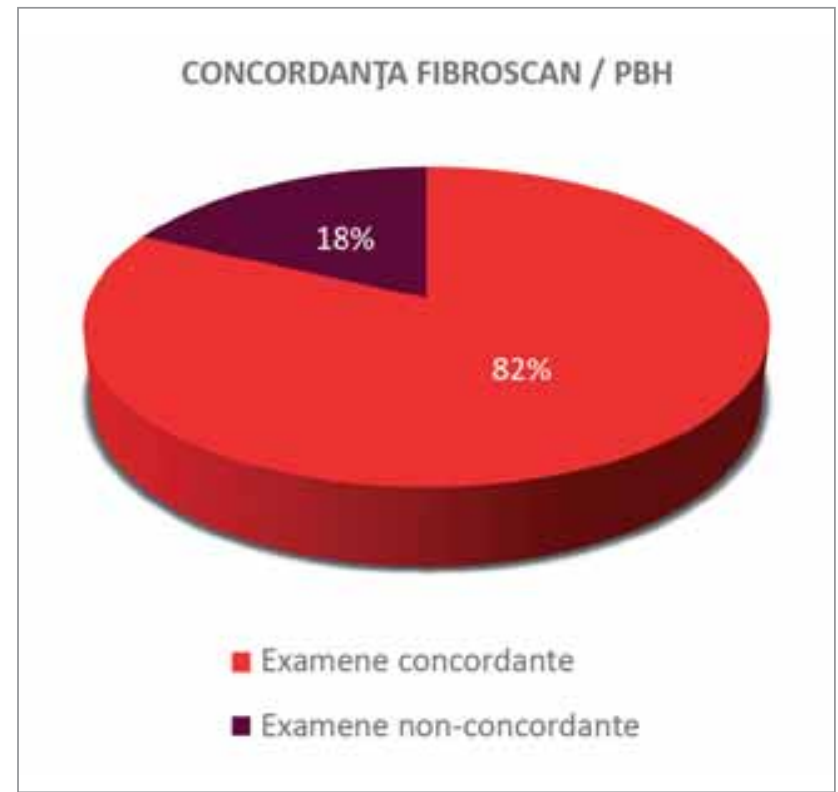

Figura 7. Concordanţa FibroScan - Punctie Biopsie Hepatică

\section{CONCLUZII}

1. FibroScan este una din metodele de evaluare non-invazivă a fibrozei hepatice cu acuratețe diagnostică asemănătoare FibroMax-ului și apropiată de a Puncției Biopsie Hepatică.

2. În hepatita cronică VHC, FibroScan evaluează fibroza hepatică cu acuratețe de $67.81 \%$ în comparație cu FibroMax și de 79.16\% în comparație cu PBH, fiind posibil în viitor, înlocuirea PBH la acestă categorie de pacienți.

3. În hepatita cronică VHB, FibroScan evaluează cu acuratețe de 75\% comparativ cu FibroMax și de 80\% comparativ cu PBH.

4. În studiul efectuat de noi, FibroScan s-a dovedit a fi o metodă simplă, reproductibilă și cu o rată foarte scazută a erorilor. 